\title{
Uitvoeringskracht in sociale wijkteams: een beproefd concept in een nieuwe context
}

\author{
Mirjan Oude Vrielink, Lydia Sterrenberg \& Helga Koper
}

Dit artikel is een themabijdrage in het kader van het VNG Jaarcongres dat op 17 en 18 juni 2014 wordt gehouden in de Drechtsteden met als thema 'Uitvoeringskracht van gemeenten'.

Gemeenten worden naar verwachting per 1 januari 2015 bestuurlijk en financieel verantwoordelijk voor werk, jeugd en maatschappelijke ondersteuning. Vooruitlopend daarop hebben vrijwel alle grote gemeenten sociale wijkteams opgericht, geïnspireerd door het succesvolle model van de Achter-de-Voordeur-aanpak. In dit artikel reflecteren we op deze ontwikkeling naar aanleiding van kritiek op de vaagheid rond de sociale teams ${ }^{1}$ en met het oog op de doorontwikkeling ervan. In een historische analyse bekijken we het fenomeen sociale wijkteams in relatie tot de politieke en beleidscontext. Onze centrale onderzoekvraag is: welke verandering in visie heeft zich voorgedaan sinds de eerste experimenten met sociale wijkteams en wat betekent dit voor de vormgeving ervan? We laten zien hoe in het beleidsdiscours gaandeweg het accent is komen te liggen op argumenten die betrekking hebben op efficiëntie van de ondersteuning, meer eigen verantwoordelijkheid en zelfregie en meer participatie in de samenleving en het arbeidsproces. Dit nodigt uit tot een andere modellering van de wijkteams, vooral in termen van (1) de doelgroep van de aanpak, (2) de diepgang van de ondersteuning en (3) de rol van de generalist en de handelingsruimte of bevoegdheden die deze generalist krijgt. De keuze van veel gemeenten om werkenderwijs te ontdekken wat werkt, kan naast de tijdsdruk een verklaring bieden voor nog vage plannen voor de inrichting en organisatie van sociale wijkteams.

\section{Inleiding}

Als alles volgens plan gaat, dragen het rijk en de provincies met ingang van 2015 taken aan gemeenten over op het gebied van maatschappelijke ondersteuning, jeugdzorg en werk en inkomen. Dit doet een extra beroep op hun uitvoeringskracht. De nieuwe taken komen immers bij de taken die gemeenten al hebben in het sociale domein, zoals de uitvoering van de Wmo, de zorg voor bijzondere bijstand en de Wet werk en bijstand (WWB). De overdracht van de nieuwe taken gaat samen met de ambitie voor een andere werkwijze: meer startend vanuit de cliënt of het gezin, meer integraal, preventief en gericht op participatie. De 
gemeenten zijn zich in een hoog tempo op de nieuwe taken aan het voorbereiden. Geïnspireerd door de ervaringen met sociale wijkteams binnen de Achter-deVoordeur-aanpak - die met een integrale aanpak voor multiprobleemhuishoudens meer wisten te bereiken tegen lagere kosten - zijn veel gemeenten nu (experimenteel) met dergelijke teams gestart. Gemeenten kiezen daarbij voor een pragmatische inslag; men gaat 'gewoon' aan de slag met het voornemen al doende te ervaren wat werkt en wat niet. Veel tijd om de inrichtingskeuzes goed te doordenken is er ook niet, en dat leidt tot een kritische houding ten aanzien van de handelwijze van gemeenten (De Koster, 2014).

Met de critici menen we dat er reden is voor reflectie. Tussen de periode waarin de sociale wijkteams zijn ontwikkeld en nu is de beleidscontext veranderd (Oude Vrielink e.a., 2013). Wat in de oude context goed werkte - het model van de wijkteams in het kader van de Vogelaar wijkenaanpak - moet in de inmiddels gewijzigde context zijn kracht nog bewijzen. De bezinning op de gemeentelijke werkwijze in de verdere doorontwikkeling van sociale wijkteams zou dan ook in het licht van deze veranderingen moeten worden bezien. Met deze bijdrage geven we hiervoor een eerste aanzet, op basis van een theoretische analyse in een historisch perspectief. Onze centrale vraag is: welke verandering in visie heeft zich voorgedaan sinds de eerste experimenten met sociale wijkteams en wat betekent dit voor de vormgeving ervan?

De opbouw van deze bijdrage is als volgt. In paragraaf 2 beschrijven we vanuit welke visie de Achter-de-Voordeur-aanpak is ontstaan en wat daarin de rol van sociale wijkteams is geweest. Paragraaf 3 behandelt de vraag binnen welke beleidscontext de stap is gezet naar een verduurzaming van de aanpak. Daarbij zal duidelijk worden dat het kabinet in de sociale wijkteams een mogelijkheid ziet om ook andere doelen dan de oorspronkelijke te helpen realiseren. In paragraaf 4 zullen we betogen dat dit uitnodigt tot een herbezinning op de inrichting en organisatie van een sociaal wijkteam. Dat laten we zien door het model van de Achterde-Voordeur-aanpak te contrasteren met een model dat past bij een aanpak gericht op meer efficiëntie van de ondersteuning, meer eigen verantwoordelijkheid en zelfregie en meer participatie in de samenleving en het arbeidsproces. We sluiten af met een korte discussie (paragraaf 5).

\section{De Achter de voordeur-experimenten: een fundamenteel vernieuwende aanpak}

De eerste ervaringen met een sociaal wijkteam zijn ontstaan binnen de wijkenaanpak van toenmalig minister Vogelaar van het programmaministerie Wonen, Wijken en Integratie (WWI). De minister constateerde dat de leefbaarheid van zogenaamde krachtwijken onder druk stond door hardnekkige maatschappelijke problemen op tal van gebieden. Veel huishoudens in deze wijken verkeerden in een achterstandspositie en dreigden uitgesloten te raken door een gebrek aan competenties en kansen om maatschappelijk te participeren en vooruit te komen. De minister vond 'een integrale en systematische aanpak [nodig] die over de gren- 
zen van de leefgebieden van bewoners heengaat' (VROM/WWI, 2007: 3). Hiervoor was in haar optiek intensieve samenwerking vereist, die niet alleen wijkgericht maar ook persoonsgericht moest worden georganiseerd (VROM/WWI, 2007: 3).

Tijdens de wijkentoer van het kabinet in 2007 gaven gemeenten aan dat ze bij de aanpak van hardnekkige sociale problematiek tegen organisatorische en financiele knelpunten aanliepen. Naar aanleiding van deze signalen besloot minister Vogelaar experimenteerruimte te creëren voor 'innovatieve en onorthodoxe aanpakken' (VROM/WWI, 2007: 14). Zij had daarbij onder meer experimenten op het oog die de 'slagkracht achter de voordeur' moesten vergroten, bijvoorbeeld door inzet van 'krachtige gezinscoaches' die de veelheid aan hulpverleners probleemgericht aan het werk zouden kunnen zetten (VROM/WWI, 2007: 16). Er kwamen zeven experimenten. Eén ervan was het Achter-de Voordeur-experiment, een gezamenlijk project van de ministeries WWI en Jeugd en Gezin en de gemeenten Amsterdam, Den Haag, Nijmegen, Eindhoven, Groningen en Enschede. Dit was geïnspireerd door een eerder gelijknamig experiment van de SEV, de Stuurgroep Experimenten Volkshuisvesting. Daarin gingen dienstverlenende instanties bij bewoners langs - in plaats van andersom - (Buddingh \& De Jong, 2006; Cornelissen e.a., 2007), waarna lokale instanties in onderlinge samenwerking met een integrale aanpak de problemen van het huishouden als geheel probeerden op te lossen (Cornelissen e.a., 2007: 7).

Deze integrale, systeemgerichte aanpak van de SEV bouwde voort op het programmaplan 'Alle kansen voor alle kinderen' uit 2007 van minister Rouvoet van Jeugd en Gezin, en op de onderliggende ervaringen met de pilot 'één kind, één plan' en experimenten met gezinscoaching (Mehlkopf, 2008). Rouvoet wilde dat hulpverleners die betrokken waren bij één gezin van elkaar wisten wat ze deden en op basis van een gemeenschappelijke diagnose zouden bepalen welke hulpverlening in het gezin nodig is. Uit hun midden moest één hulpverlener als coördinator optreden; die zou het overzicht hebben en het aanspreekpunt voor het gezin en de andere hulpverleners zijn (Programmaministerie Jeugd en Gezin, 2007: 17). Zo ontstond een aanpak gebaseerd op intensieve samenwerking en ketenregie, waarbij in één plan voor het gehele gezin afspraken werden gemaakt over de inhoud en uitvoering van de hulpverlening.

\section{Van ketenregie en samenwerking naar generalistisch werken}

Draaide het bij Rouvoet nog om jeugdzorg, binnen het Achter-de-Voordeur-experiment van Vogelaar ontwikkelden de steden projecten en praktijken om huishoudens met meervoudige, complexe problematiek te bereiken - huishoudens die hun problemen niet zelf konden of wilden oplossen. Vanwege de schotten in regelingen en financieringsstromen die een effectieve aanpak in de weg stonden, experimenteerde men met een onorthodoxe werkwijze die in de plaats kwam van de ketenregie en intensieve samenwerking uit het programmaplan 'Alle kansen voor kinderen'. In plaats van die ketenregie kwam intra-professionele coördinatie (vergelijk Oldenhof, 2014) met gelegenheid om in teamverband andere professio- 
nals te consulteren, voeden en coachen. En in plaats van intensieve samenwerking in de uitvoering, kwam de professional met een feitelijk handelingsmandaat om zelf op alle leefgebieden eerstelijns activiteiten uit te voeren. Alleen als de kennis of kunde binnen het wijkteam ontoereikend was of een specialistisch aanbod nodig was, werd de tweedelijn ingeschakeld. Zo konden de professionals zelf in samenspraak met het huishouden beslissen welke hulp nodig was en dit in gang zetten.

\section{Van experiment naar verduurzaming: de aanpak in nieuw vaarwater}

Experimentele aanpakken vallen vaak ten prooi aan 'de projectencarrousel' (Gilthay Veth e.a., 2012), maar het Achter-de-Voordeur-experiment is aan dit lot ontsnapt; sterker nog, de aanpak heeft zich 'als een veenbrand' verbreid (Kruiter \& Kruiter, 2013: 4). Dat is te danken aan de positieve ervaringen van de zes steden die aan de wieg van de nieuwe aanpak stonden en het gunstige politieke klimaat. Het experiment kreeg een landelijk vervolg in het AdV/MPG-project, recent omgedoopt tot Integrale Aanpak. En een intensieve lobby vanuit de grote steden leidde er toe dat het een plek kreeg in het regeerakkoord 'Bruggen slaan' uit 2013. De aanpak wordt hierin bepleit als 'het uitgangspunt voor de drie decentralisaties'. In zijn brief over de langdurige zorg, deed ook staatssecretaris Van Rijn een duit in het zakje met de toezegging 50 miljoen Euro te investeren in het opzetten van sociale wijkteams als verbindende schakel tussen het sociale en medische domein (TK 30597 nr. 296, p. 2).

\section{Verbreding van het beleidsdiscours}

Met het regeerakkoord ging ook het vigerende beleidsdiscours rond de sociale wijkteams schuiven. Aanvankelijk koppelt het kabinet de 'één gezin, één plan, één regisseur'-aanpak aan het streven dat er 'een einde [komt] aan de praktijk waarbij vele hulpverleners langs elkaar heen werken bij de ondersteuning van één gezin' (2012: 24). Hiermee wordt nog aangesloten bij de doelstelling van de eerste experimenten. Ook de doelgroep blijft in eerste instantie nog die van multiproblematiek-gezinnen, zoals blijkt uit de eerste decentralisatiebrief van coördinerend minister Plasterk. Verwijzend naar dergelijke gezinnen stelt de minister dat de '[i]nzet moet zijn dat er één persoon is die hen namens de gemeente ondersteunt en begeleidt op basis van een integraal plan voor het gehele huishouden (TK 33 400, nr. 59, p. 1)'. Maar in dezelfde brief wordt ook de latere denklijn al zichtbaar: de bijdrage die een integrale en meer preventieve aanpak kan leveren aan de kostenbeheersing komt centraal te staan en bij het organiseren van de aanpak op maat vormen eigen kracht, zelfredzaamheid en participatie het uitgangspunt.

De accentverschuiving in het beleidsdiscours zien we terug ook in de beleidsnotities waarin de sectorspecifieke aanleidingen voor de decentralisaties staan beschreven. Daarin tekent zich een domein overstijgende probleemdefinitie af, waarin drie problemen centraal staan (zie ook kader). Ten eerste is de wijze waarop ondersteuning in het huidige stelsel wordt geboden volgens de verant- 
woordelijke bewindslieden te gefragmenteerd als gevolg van gescheiden regelingen en financieringsstromen. En de verkokering en versnippering werken regeldruk en perverse prikkels in de hand en leiden tot dure maar niet altijd effectieve zorg-, hulp- en dienstverlening. Ten tweede vormt, naast problemen in de organisatie van de ondersteuning, ook de passieve en consumptieve houding van burgers een probleem. In de optiek van de bewindslieden doen burgers onvoldoende mee in de samenleving en het arbeidsproces en dragen zij te weinig zorg voor elkaar. En het derde, politiek gezien meest dringende, probleem is de financiële onhoudbaarheid van het bestaande stelsel. Dit wordt in belangrijke mate gezien als uitvloeisel van het recht op zorg/compensatiebeginsel en een steeds uitdijend aanbod, waardoor burgers en aanbieders geen prikkel ervaren om op zoek te gaan naar goedkopere oplossingen. Ook in de oplossingsrichting tekent zich een gedeelde visie af (vergelijk Movisie, 2012): gemeenten, als meest nabije overheid voor de burger, worden als de aangewezen bestuurslaag gezien om de nieuwe doelen van meer effectiviteit en efficiëntie, lagere kosten, meer zelfregie en eigen verantwoordelijkheid en meer participatie in de samenleving en op de arbeidsmarkt te realiseren.

Eén gezin, één plan, één regisseur in de sectorspecifieke wetsvoorstellen

Op het terrein van de jeugdzorg wordt de integrale aanpak gekoppeld aan 'normalisering' en een laagdrempelig, vroegtijdig aanbod. Hierin ligt volgens de Memorie van Toelichting bij de nieuwe Jeugdwet een prikkel besloten om extra te investeren in preventie en lichte ondersteuning, waardoor het beroep op specialistische en gedwongen hulp zal verminderen (TK 33684 nr. 3, p. 14). Professionals en mensen uit het sociale netwerk die bij een gezin zijn betrokken werken samen met de gezinsleden aan zoveel mogelijk 'herstel van het gewone leven' (TK 33684 nr. 3, p. 17). Het uiteindelijke doel is de eigen kracht van de jongere en van diens gezin en sociale omgeving te versterken. Dit reikt verder dan alleen het voorkomen dat overheidsbemoeienis leidt tot zorgafhankelijkheid; die bemoeienis moet juist actief bijdragen aan het versterken van het zorgend en probleemoplossend vermogen van de jongere en zijn omgeving (TK 33684 nr. 3, p. 14).

Op het domein van de maatschappelijke ondersteuning moet de integrale benadering zorgen voor afgestemde dienstverlening in de ondersteuning van de zelfredzaamheid en participatie van mensen met een beperking, chronische psychische of psychosociale problemen, zodat mensen zo lang mogelijk in de eigen leefomgeving kunnen blijven (TK 33841 nr. 3, p. 1). In een onderzoek volgend op een melding van een ondersteuningsbehoefte bepaalt de gemeente of ondersteuning nodig is en zo ja, of het mogelijk en wenselijk is voorzieningen in samenhang aan te pakken. De integrale aanpak moet ervoor zorgen dat zo min mogelijk mensen afhankelijk raken van maatschappelijke ondersteuning en dat zij beter en doelmatiger worden 
ondersteund, waarbij langs elkaar heen werken wordt voorkomen (TK 33 841 nr.3, p. 18).

Voor taken die gemeenten krijgen op het gebied van werk en inkomen vormt het voorstel voor de Participatiewet een belangrijk kader. De doelgroep wordt gevormd door mensen met arbeidsvermogen die zijn aangewezen op, al dan niet tijdelijke, ondersteuning om in hun bestaan te voorzien en/of op ondersteuning om aan het werk te komen (TK 33 161, nr. 107, p. 32). De inzet van het wetsvoorstel is om iedereen met arbeidsvermogen naar werk toe te leiden, bij voorkeur naar regulier werk omdat dit de zelfontplooiing, eigenwaarde en sociale contacten bevordert (TK 33 161, nr. 107, p. 32). Gemeenten stellen op basis van een diagnose vast wie op eigen kracht aan de slag kan komen en wie daarvoor ondersteuning nodig heeft, en in welke vorm (TK 33 161, nr. 107, p.45). Het uitgangspunt van 'één gezin, één plan, één regisseur' wordt daarbij gezien als een doel dat gemeenten dichterbij kan brengen door instrumenten en voorzieningen die door de Participatiewet en de andere decentralisaties beschikbaar komen in samenhang en integraal in te zetten. En door de eigen kracht van mensen te benutten en zoveel mogelijk aan te sluiten bij de specifieke leefsituatie van mensen, kan de gemeente zorgen dat inzet van middelen doelmatiger en doeltreffender wordt (TK 33161 nr. 107, p. 37).

\section{Nieuwe keuzeruimte en consequenties}

Deze nieuwe doelen en ingeboekte efficiencykortingen stellen gemeenten voor de opgave om tot een andere structuur en werkwijze te komen en een cultuuromslag te bewerkstelligen bij burgers én professionals (Op het Veld \& Wachtmeester, 2012; Movisie, 2012: 6). Door de decentralisaties kunnen gemeenten een lokaal samenhangend stelsel van maatschappelijke ondersteuning bieden op voor de burger belangrijke leefgebieden: opvoeding, zorg, welzijn, arbeidsparticipatie en inkomensondersteuning, zo is de gedachte. De (wettelijke) kaders laten open hoe de gemeenten dat doen. Voortbordurend op de achter-de-voordeur-aanpak kiezen veel gemeenten voor een gebiedsgerichte aanpak met sociale wijkteams, veelal in de vorm van een pilot of experiment om al doende uit te vinden wat werkt. De kritiek hierop is dat gemeenten blijven steken in algemeenheden en vaagheid: 'Het wordt niet concreet. Wie is die regisseur, wat doet deze persoon, hoe worden indien nodig specialisten ingezet en hoe verhoudt die inzet zich tot de regisseur en het sociale wijkteam?' (De Koster, 2014: 7). Het gevaar van de pragmatische insteek van de gemeenten is a dat als niet helder is waarom met sociale wijkteams wordt gewerkt, gemeenten in onzekerheid blijven over de werkzaamheid van gemaakte keuzen.

Om een (eerste) beeld te krijgen van wat werkt en wat daarvoor precies moet worden georganiseerd, zetten we in deze paragraaf twee (ideaaltypische) praktijken naast elkaar, die inzichtelijk maken hoe een ander accent in de doelstellingen zijn 
weerslag kan hebben op de modellering van de sociale teams. We vergelijken de achter-de-voordeur-aanpak met een tweede aanpak, die de denklijn van de decentralisaties en de rol van sociale wijkteams daarin weerspiegelt. De beide aanpakken hebben gemeenschappelijk dat zij zich richten op huishoudens met meervoudige problematiek, maar voor het overige hebben zij inhoudelijk en organisatorisch een eigen profiel. We beschrijven hieronder de beide profielen en reflecteren vervolgens op de betekenis van de gevonden verschillen.

De eerste praktijk halen we uit het e-book 'Aan de slag achter de voordeur'. Hierin beschrijven de zes gemeenten van het achter-de-voordeur-experiment op basis van hun ervaringen 'een ideale context' (of voorwaarden) voor hun praktijk. De elementen waaruit deze context volgens de steden bestaat, geven we hieronder letterlijk weer (2010: 15):

- Beschikbaarheid van ervaren brede professionals met handelingsruimte om vanuit moraliteit en empathie een relatie met een multiprobleemhuishouden op te bouwen. Deze professionals fungeren als regisseur; zij zijn in staat om op basis van (geaccepteerde) integrale diagnostiek met het huishouden te komen tot een herstelplan gericht op stabilisatie en/of een plan gericht op het vergroten van welzijn dan wel sociale stijging van individuele leden van het gezin.

- Afspraken met deze regisseur (c.q. samenwerkingsovereenkomst) om in het plan van aanpak op maat gebruik te maken van specialistische hulpverlening.

- Beschikbaarheid voor deze regisseur van hulp en instrumenten om een maatschappelijk steunsysteem in en om deze gezinnen te bouwen.

- De regisseur is voor langere tijd en ook buiten kantooruren beschikbaar, is makkelijk toegankelijk/ bereikbaar en werkt vanuit de presentie-methode.

- De regisseur kan werken vanuit een team waarvan de leden voortkomen uit de verschillende kokers (multidisciplinair); teamleden zijn 'generalist in de wijk, specialist in het team'.

- Het multidisciplinaire team is in de gelegenheid om met de uitvoerders, studenten, wetenschappelijk (praktijk)onderzoekers en netwerkpartners een lerende omgeving te vormen.

- Er wordt permanent aan effectiviteitsmeting gedaan en er worden stappen ondernomen om de maatschappelijke en financiële baten van de aanpak te benoemen door de toepassing van maatschappelijke kosten-batenanalyses.

De tweede ideaaltypische praktijk, in onze termen de 'Burgerkracht-aanpak', waarin ook de doelen van de decentralisaties worden betrokken, halen we uit de handreiking 'Integrale aanpak multiproblematiek en arbeidstoeleiding' (Nijhof \& De Levita, 2012). Deze tweede handreiking is gebaseerd op ervaringen van professionals in het veld, programma's en bewezen methodieken. ${ }^{2}$ Net als in de Achterde-Voordeur-aanpak zien de auteurs het gebrek aan samenhang in de

2 Deze handreiking is geschreven in opdracht van het ministerie van SZW in samenwerking met VWS, OCW, BZK en V\&J ter ondersteuning van gemeenten in hun nieuwe verantwoordelijkheid om ook voor burgers met meervoudige problemen (arbeids)participatie te realiseren. De aanpak staat aan de wieg van de sociale wijkteams zoals die in Zaandam opereren. 
ondersteuning van mensen met meervoudige problematiek als een probleem van het huidige systeem en zij wijten dit eveneens aan het grote aantal hulpverleners in een huishouden, de oriëntatie op deelproblemen en een op individuen gerichte aanpak en een gebrek aan samenwerking door schotten in de financiering. De auteurs zien ook twee andere problemen in het huidige stelsel, namelijk een gemis aan preventief werken en het feit dat de toeleiding naar werk en hulpverlening gescheiden werelden zijn. Het gemis aan preventief werken ontstaat volgens de auteurs door het ontbreken van 'doorzettingsmacht' en onevenredig veel aandacht voor zware multiproblematiek en crisissituaties (2012: 11, 12). Om tot meer samenhang te komen, achten de auteurs de Achter-de-Voordeur-aanpak effectief, maar toch ongeschikt omdat de aanpak te veel geld en tijd kost (2012: 15). $\mathrm{Zij}$ zoeken de oplossing in snel en kortdurend ingrijpen in de eerstelijn door een generalist die de eigen kracht en het eigen sociale netwerk van de klant weet op te bouwen en te benutten, die de sociale kaart kent en weet wat er moet gebeuren en die zelf snel kan handelen (2012: 15). De aanpak is gericht op meervoudige problematiek, mits de problemen niet te complex zijn of langdurige ondersteuning vergen (2012: 8, 35).

Uit de handreiking leiden we verder af dat voor deze aanpak in contextuele zin ieder geval de volgende elementen van belang zijn:

- Er is voor de aanpak van multiproblematiek een brede generalist, een spin in het web met handelingsruimte en mandaat. ${ }^{3}$ Deze generalist werkt op verschillende leefgebieden en heeft zelf deskundigheid op één of meerdere leefgebieden. De generalist coacht, structureert en stimuleert de eigen kracht van mensen (2012: 19). Kernelementen bij het inrichten van de integrale aanpak bij multiproblematiek zijn het opbouwen van een vertrouwensrelatie, aansluiting op de probleembeleving en motivatie van de burger en het versterken van zelfsturing (2012: 29, 30).

- Als meteen duidelijk is dat de te ondersteunen burger het niet redt met kortdurende ondersteuning, dan verwijst de generalist door naar specialisten in de tweede lijn (2012: 19).

- De generalist kan beschikken over instrumenten voor een integrale diagnose en over onderbouwde en effectieve methoden en instrumenten om huishoudens met multiproblematiek te ondersteunen (2012: 25-30).

- Het sociaal team kan vanuit een bewust gekozen benadering werken (bijvoorbeeld systeembenadering, holistische benadering, presentiebenadering, individuele vraaggerichte benadering of gedragsbenadering) (2012: 19-21).

- In het integrale sociale team zitten mensen met deskundigheid op verschillende leefgebieden, zodat de teamleden elkaar kunnen aanvullen. De teamleden stemmen hun aanpak onderling af, maar er wordt geen nieuwe overlegstructuur gevormd (2012: 19).

3 Professionals moeten handelingsruimte krijgen om dicht bij de klant te staan en om buiten protocollen om te onderzoeken hoe de regie weer bij de individuele klant of het huishouden als geheel kan worden neergelegd. Om maatwerk te kunnen leveren hebben de professionals mandaat nodig in de zin van de bevoegdheid en een budget om kortdurende interventies in te zetten (2012: 30). 
- Het werken met een integraal sociaal team vraagt om een andere manier van denken en handelen en daarvoor is een lerende organisatie en een continue ontwikkeling van het team en haar deskundigheid nodig; het vraagt om steeds bijsturen op basis van evaluatie, intervisie en monitoring van resultaten (2012: 39).

\section{Vergelijking}

De bovenstaande elementen van een 'gunstige context' laten zich in navolging van Dodeweerd en Westerhof (2012: 35-43) in drie bestanddelen uiteenleggen: de elementen 1. die inzichtelijk maken uit welke de onderdelen de ondersteuning bestaat, 2. die beschrijven waaruit de ondersteunende rol van de professional bestaat en 3. die aangeven hoe de ondersteuning in randvoorwaardelijke zin vorm moet krijgen. In tabel 1 passen we die indeling toe op de twee ideaaltypische praktijken. Dit maakt in één oogopslag inzichtelijk wat beide praktijken kenmerkt in termen van de probleemdefinitie, doelen, oplossingsrichting, doelgroep en de werkzame bestanddelen. De tabel leert dat er drie belangrijke verschillen zijn tussen de twee praktijken: in doelgroep, in de rol van de 'generalist' en in het ondersteuningsbereik. Hierna gaan we verder in op de betekenis van de verschillen.

\section{Betekenis van een verschillende doelgroep}

Het verschil in doelgroep heeft consequenties voor de samenstelling en 'diepte' van een sociaal team en benodigde bevoegdheden. In situaties van complexe, meervoudige problematiek hebben huishoudens op verschillende leefgebieden problemen die onderling verweven zijn (Ghesquière, 1993; Steketee \& Vandenbroucke, 2010). Dat betekent dat generalisten veel signalen moeten kunnen herkennen, moeten kunnen begrijpen hoe problemen op elkaar inwerken en op veel leefgebieden ondersteuning moeten kunnen bieden. In vergelijking hiermee is voor ondersteuning bij lichtere, meervoudige problematiek minder diepgaande kennis en kunde nodig, waardoor er meer gelegenheid is om het eigen netwerk of informele verbanden in te schakelen dan bij complexe problematiek (vergelijk 'Aan de slag achter de voordeur', 2011: 14). Verder is voor complexe problematiek vaak specialistisch aanbod nodig, waardoor de vraag aan de orde is of ook specialistische functies in het team worden belegd. Wordt daar niet voor gekozen, dan vraagt de integrale aanpak om afspraken die een generalist een zekere doorzettingsmacht geven, zoals beslissings- of indicatiebevoegdheden.

Daarnaast heeft de doelgroep ook consequenties voor de mogelijkheid van een vernieuwend aanbod. De verwevenheid van problemen en het ontbreken van een algemeen profiel van huishoudens met complexe problematiek (Steketee \& Vandenbroucke, 2010: 37) maakt dat werkprocessen bij complexe, meervoudige problematiek rond de specifieke situatie van het huishouden moeten worden georganiseerd (Mehlkopf, 2008; Uittenbogaard e.a., 2010: 20, 196-197). Om juist dat mogelijk te maken is het model van de sociale wijkteams met de generalistische werkwijze ontwikkeld. Voor lichtere, meervoudige problematiek geldt dat huishoudens met enige extra inspanning binnen de reguliere werkprocessen te helpen zijn. Dat kan door afstemming tussen hulpverleners al dan niet aangevuld met 
Tabel 1: Vergelijking tussen de twee ideaaltypische praktijken

\begin{tabular}{|c|c|c|}
\hline & Achter-de-Voordeur-aanpak & 'Burgerkracht-aanpak' \\
\hline \multirow[t]{3}{*}{ Probleemdefinitie } & $\begin{array}{l}\text { Problemen worden vanuit een } \\
\text { beperkt perspectief gefragmen- } \\
\text { teerd aangepakt }\end{array}$ & $\begin{array}{l}\text { Problemen worden vanuit een beperkt } \\
\text { perspectief gefragmenteerd aangepakt }\end{array}$ \\
\hline & $\begin{array}{l}\text { Ondersteuning is aanbodgericht } \\
\text { en individueel }\end{array}$ & $\begin{array}{l}\text { Ondersteuning is aanbodgericht en } \\
\text { individueel }\end{array}$ \\
\hline & $\begin{array}{l}\text { Alleen bij hulpvraag actie, terwijl } \\
\text { mensen niet altijd om hulp kun- } \\
\text { nen of willen vragen }\end{array}$ & $\begin{array}{l}\text { Door laat ingrijpen zijn problemen al } \\
\text { geëscaleerd, waardoor dure vormen } \\
\text { van ondersteuning nodig zijn }\end{array}$ \\
\hline Doel van aanpak & $\begin{array}{l}\text { Stabilisatie en/of vergroten van } \\
\text { welzijn dan wel realiseren van } \\
\text { sociale stijging }\end{array}$ & $\begin{array}{l}\text { Terugdringen beroep op tweede lijn } \\
\text { door preventief en snel ingrijpen en } \\
\text { bevorderen (arbeids)participatie }\end{array}$ \\
\hline Doelgroep & $\begin{array}{l}\text { Huishoudens met complexe, } \\
\text { meervoudige problematiek }\end{array}$ & $\begin{array}{l}\text { Huishoudens met niet al te zware, } \\
\text { meervoudige problemen }\end{array}$ \\
\hline \multirow{2}{*}{$\begin{array}{l}\text { Inhoudelijke aspec- } \\
\text { ten van de onder- } \\
\text { steuning }\end{array}$} & $\begin{array}{l}\text { Aansluiting zoeken bij intrinsieke } \\
\text { vermogen c.q. motivatie }\end{array}$ & $\begin{array}{l}\text { Zoeken naar vraag achter de vraag en } \\
\text { naar wat iemand zelf kan en wil }\end{array}$ \\
\hline & Werken aan sociaal herstel & $\begin{array}{l}\text { Werken aan sociaal herstel en active- } \\
\text { ren naar werk of andere participatie- } \\
\text { vormen }\end{array}$ \\
\hline \multirow[t]{3}{*}{$\begin{array}{l}\text { Rol van professional } \\
\text { in de ondersteuning }\end{array}$} & $\begin{array}{l}\text { Vertrouwensrelatie opbouwen, } \\
\text { waar nodig grenzen stellen }\end{array}$ & $\begin{array}{l}\text { Vertrouwensrelatie opbouwen, } \\
\text { waar nodig grenzen stellen }\end{array}$ \\
\hline & $\begin{array}{l}\text { Ondersteunen naar hernemen } \\
\text { zelfregie }\end{array}$ & $\begin{array}{l}\text { Ondersteunen naar (her)nemen van } \\
\text { zelfregie }\end{array}$ \\
\hline & $\begin{array}{l}\text { Bouwen van sociale netwerken } \\
\text { en steunsystemen }\end{array}$ & $\begin{array}{l}\text { Bouwen van sociale netwerken en } \\
\text { steunsystemen }\end{array}$ \\
\hline \multirow{8}{*}{$\begin{array}{l}\text { Vormgeving van de } \\
\text { ondersteuning }\end{array}$} & Outreachend & Outreachend \\
\hline & Methodisch werken & Methodisch werken \\
\hline & $\begin{array}{l}\text { Integrale diagnose om een her- } \\
\text { stelplan op maat te maken }\end{array}$ & $\begin{array}{l}\text { Integrale diagnose of professionele } \\
\text { ondersteuning nodig is en zo ja, welke }\end{array}$ \\
\hline & $\begin{array}{l}\text { Ondersteuning zo lang en inten- } \\
\text { sief als nodig }\end{array}$ & Kortdurende interventies \\
\hline & Generalistisch werken & Generalistisch werken \\
\hline & $\begin{array}{l}\text { Waar nodig tweede lijn inscha- } \\
\text { kelen voor consultatie of specia- } \\
\text { listisch aanbod }\end{array}$ & $\begin{array}{l}\text { Complexe problematiek meteen door- } \\
\text { verwijzen naar tweedelijn }\end{array}$ \\
\hline & $\begin{array}{l}\text { Waar mogelijk sociaal netwerk } \\
\text { betrekken }\end{array}$ & $\begin{array}{l}\text { Mobiliseren eigen netwerk en collec- } \\
\text { tief aanbod faciliteren/ondersteunen }\end{array}$ \\
\hline & $\begin{array}{l}\text { Generalist is regisseur: regie op } \\
\text { casus en regie op uitvoering }\end{array}$ & Generalist is intermediair \\
\hline
\end{tabular}

ketenregie (Uittenbogaard e.a., 2010: 20, 196-197). Dat dit onvoldoende gebeurt, komt door 'verkeerde prikkels' in het huidige stelsel. Deze maken dat professionals weinig gebruikmaken van ruimte om maatwerk te leveren (Kruiter e.a., 2008: 55) en dat initiatieven tot afstemming en samenwerking doorgaans uitblijven (Mehlkopf, 2010: 157, 161). Dit laat onverlet dat bij lichtere, meervoudige problematiek in principe de mogelijkheid bestaat om huishoudens in te passen in 
bestaande werkprocessen. Dat betekent dat voor deze huishoudens rond veel voorkomende probleemcombinaties nieuwe arrangementen zijn te organiseren (vergelijk Soeters \& Verhoeks, 2010), waar dit voor huishoudens met complexe, meervoudige problematiek geen reële optie is.

\section{Betekenis van de keuze om de generalist (g)een regisseur te laten zijn}

In de Achter-de-Voordeur-aanpak krijgt de generalist de rol van regisseur om te zorgen voor een goede uitvoering van het integrale plan van aanpak dat met het huishouden samen is opgesteld. In de rol van regisseur moet de generalist contact leggen en onderhouden met professionals en instellingen die nodig zijn voor de uitvoering van het plan van aanpak. Daartoe moeten afspraken worden gemaakt over wat verschillende partijen doen en wanneer. De generalist bewaakt vervolgens de voortgang en ziet toe op de naleving van de gemaakte afspraken. Omdat het van de andere partijen vraagt om zich naar het plan van aanpak te voegen en hier procedures, protocollen en belangen aan in de weg kunnen staan, is het nemen van de regierol niet eenvoudig. Het vergt tijd en energie die de generalist niet kan besteden aan het huishouden zelf.

Omdat de alternatieve aanpak inzet op kortdurende interventies, wordt bewust van de rol van regisseur afgezien. Waar de problematiek zodanig complex is dat een regierol nodig is, draagt de generalist het huishouden aan de tweedelijn over. De consequentie hiervan in dat een sociaal team alleen binnen de eerstelijn voor een integrale aanpak kan zorgen. Daarmee neemt de kans op kostenbesparing af. Dit risico is het grootst als meerdere hulpverleners vanuit een individuele benadering de zorgcoördinatie op zich nemen voor die delen van de problematiek waarvoor zij verantwoordelijk zijn. Als de casus wordt overgedragen aan een integraal team in de tweedelijn, dan is dit risico beperkt. Er kan dan een aantrekkelijke tandem-constructie ontstaan als de generalist zich specialiseert in samenlevingsopbouw om de eigen kracht maximaal te benutten en de regisseur in de tweedelijn na hulpverlening weer 'afschaalt' zodra de problemen in de eerstelijn hanteerbaar zijn. Op deze manier hoeft niet elke generalist 'een schaap met de vijf poten' te zijn en krijgt een sociaal team meer ruimte om te schakelen tussen individuele vraagstukken van huishoudens en collectieve vraagstukken in de wijk. ${ }^{4}$

\section{Betekenis van een verschillende inhoudelijke oriëntatie}

In de Achter-de-Voordeur-aanpak sluit het ondersteunen van eigen kracht nauw aan op de methodiek van De Kanteling en de principes van Welzijn Nieuwe Stijl. De alternatieve 'Burgerkracht-aanpak' gaat met een sterk activerende rol nog een stap verder. In lijn met de wetsvoorstellen Wmo 2015 en Participatiewet wordt alleen ondersteund waar een huishouden het niet alleen redt, ook niet met hulp van het sociale netwerk. De generalist heeft dan als rol om de eigen kracht van het huishouden en de sociale omgeving te versterken, te bemiddelen tussen de 
hulpvraag en informele ondersteuning, wederkerigheid te bevorderen en burgers rond een collectief aanbod te verbinden. Het werken vanuit presentie in de wijk vormt daarmee een wezenlijk onderdeel van de aanpak en vraagt van het wijkteam om naast hulpvragers ook aandacht te hebben voor mensen die iets voor een ander kunnen betekenen. Dit vraagt in de samenstelling van het team om expertise op het gebied van samenlevingsopbouw. En als de activering ook gericht is op arbeidsre-integratie, dan is ook expertise op dit terrein in het team nodig.

\section{Discussie}

We begonnen dit artikel met de constatering dat vrijwel alle grote gemeenten, aan de vooravond van de decentralisaties in het sociale domein, sociale wijkteams hebben opgericht. Daarmee hebben ze de gebiedsgerichte, integrale en de generalistische werkwijze van het Achter-de-Voordeur-experiment overgenomen. Gemeenten en Rijk zagen en zien de teams als een prima model om beoogde structuurverandering en cultuuromslag in het sociale domein vorm te geven, waar de decentralisaties op aansturen. In het kielzog hiervan heeft er een verschuiving plaatsgevonden in de doelen waarvoor de sociale wijkteams kunnen worden ingezet. De aanpak van een integraal plan voor het huishouden als geheel kwam vanuit de jeugdzorg en werd overgenomen in het kader van de Vogelaarwijkaanpak. Daarmee werden huishoudens met complexe multiproblematiek, die teveel hulpverleners over de vloer kregen en daar niet mee overweg konden, de doelgroep van een wijkgerichte benadering gericht op een effectievere aanpak met als uiteindelijk doel sociale stijging. Nu, bij de decentralisaties, wordt de aanpak vanuit kostenoverwegingen nadrukkelijk gekoppeld aan een integrale en meer preventieve aanpak en het benutten en stimuleren van eigen kracht en participatie. Dit verklaart waarom het stimuleren van burgerkracht zo'n belangrijke doelstelling is, tot verbazing van enkele onderzoekers die hadden verwacht dat gemeenten de sociale teams in lijn met de oorspronkelijke insteek 'vooral willen inzetten als middel om een betere afstemming tussen verschillende hulpverleners te bewerkstelligen, en dat minder professionele drukte tot meer slagvaardigheid moet leiden (De Koster, 2014: 7)'.

Ook de in de inleiding al aangehaalde kritiek van deze onderzoekers op de vaagheid van de beleidsnota's is in het licht van het voortschrijdende beleidsdiscours te duiden. De verschuiving in doelstellingen brengen namelijk nieuwe organisatieen inrichtingsvragen met zich mee. Dit nodigt uit tot het uitproberen van varianten op het oorspronkelijke model. De pragmatische inslag van gemeenten, mede ingegeven door het tempo van de decentralisaties, maakt dat sociale wijkteams werkenderwijs en 'van onderop' worden ontwikkeld. Onze vergelijking van twee ideaaltypische aanpakken - de Achter-de-Voordeur-aanpak en de 'Burgerkrachtaanpak' - illustreert welke verschillen dit met zich mee kan brengen in de doelgroep, de rol van de generalist en het ondersteuningsbereik. Het onderstreept het pleidooi van critici voor meer helderheid over de doelstellingen en gewenste effecten en meer concreetheid over de inrichting en organisatie van de teams. Zij ver- 
wachten hiervan een louterend effect op al te overspannen verwachten van wat een sociaal team vermag.

In de context van het Achter-de-Voordeur-experiment lukte het om met het model van sociale wijkteams meer te bereiken voor multiprobleemhuishoudens tegen lagere kosten. Of dit ook lukt onder de huidige condities moet zich nog bewijzen en dat geldt helemaal voor de vraag of het model ook kan bijdragen aan het realiseren van andere doelstellingen dan een beter afgestemde en meer slagvaardige aanpak van problemen van multiprobleemhuishoudens. Zijn bijvoorbeeld de factoren die specifiek werkzaam zijn gebleken voor de benadering en de inhoud van de ondersteuning van multiprobleemhuishoudens (vergelijk Berg-le Clercq e.a., 2012) ook relevant als de aanpak zich primair richt op het ondersteunen van burgerkracht, om maar iets te noemen? En wat betekenen andere doelstellingen voor het profiel van de generalist? Zijn de profielen die landelijk zijn opgesteld als handreiking voor de steden geschikt ongeacht de aanpak die de gemeente kiest of vergen de rollen verschillende competenties? En vragen verschillende doelstellingen wel hetzelfde van een sociaal team? Denk bijvoorbeeld aan het stimuleren van eigen kracht en het reduceren van kosten door preventief ingrijpen: het eerste vraagt van het wijkteam om eerst te proberen wat met zo min mogelijk professionele ondersteuning kan worden bereikt, maar met het risico dat de eigen kracht en informele ondersteuning uiteindelijk niet toereikend blijkt en problemen ondertussen zo zijn verergerd dat duurdere professionele ondersteuning nodig is dan wanneer meteen meer eerstelijnsondersteuning zou zijn geboden (de zogenaamde interventieparadox).

Voor een antwoord op deze en andere vragen is het nog te vroeg, maar ze onderstrepen het belang van reflectie zodat gemeenten en het Rijk realistisch blijven als het gaat om de rol die sociale wijkteams kunnen vervullen in een veld in beweging met schuivende panelen.

\section{Literatuur}

Aan de slag achter de voordeur. Van signaleren naar samenwerken, E-book geschreven in opdracht van het ministerie van BZK en het ministerie van VWS, directie Jeugd, Den Haag: 2011.

Berg-le Clercq, T., M. Zoon \& A. Kalsbeek, Wat werkt in multiprobleemgezinnen?, augustus 2012.

Buddingh, I. \& J. de Jong, Achter de voordeur Woonmaatschappelijk werk nieuwe stijl. Verkenning projecten 'Achter de voordeur', SEV-programma Keer de verloedering, juni 2006.

Cornelissen, E., T. Brandsen, m.m.v. E. Dané, Handreiking 'Achter de voordeur'. Een verkennend onderzoek naar zeven grootstedelijke 'Achter de Voordeur'-projecten, SEV-programma Keer de verloedering, 2007.

Dodeweerd, M. van \& E. Westerhof, Bouwstenen voor het sociale domein. Kennis voor de verknoping van zorg, participatie en werk, Divosa, Utrecht: november 2012.

Ghesquière, P., Multiprobleemgezinnen, Leuven/ Apeldoorn: 1993 
Giltay Veth, D., P. van der Hoeven, T. Trooster \& Y. Wijland, De rem op de projectencarrousel. Geleerde lessen in 2010 en 2011, Eindpublicatie van het experiment 'aanpak van de projectencarrousel', mei 2012.

Koster, Y. de, Vaagheid troef bij sociale wijkteams, Binnenlands Bestuur, 17 januari 2014.

Kruiter, A.J, C. Hijzen, J. de Jong \& J. van Niel, De Rotonde Van Hamed. Maatwerk voor mensen met meerdere problemen, Nicis Instituut, Den Haag: 2008.

Kruiter, A.J. \& H. Kruiter, De praktijk als landingsbaan, in opdracht van het ministerie van BZK en het ministerie van VWS, mei 2013.

Mehlkopf, P., Een kwestie van goed regelen. Over multiprobleemgezinnen, coördinatie van zorg en gezinscoaching. Handreiking bij implementatie, Expertisecentrum voor Jeugd, Samenleving en Opvoeding (JSO), Gouda: 2008.

Mehlkopf, P., Zorgcoördinatie en gezinscoaching, B.P. Uittenborg (ed.), Werken met multiprobleemhuishoudens, Baarn: 2010, p. 156-166.

Ministerie van Binnenlandse Zaken en Koninkrijksrelaties, Kamerbrief aanpak decentralisaties op terrein van ondersteuning, participatie en jeugd, Den Haag: 19 februari 2013.

Ministerie van Binnenlandse Zaken en Koninkrijksrelaties, Projectplan Achter de Voordeuraanpak / Multiprobleemgezinnen, Den Haag: augustus 2012

Ministerie van Volksgezondheid, Welzijn en Sport, Kamerbrief hervorming langdurige zorg: naar een waardevolle toekomst, (TK 30 597, nr. 296), Den Haag: 25 april 2013.

Nijhof, W. \& B. de Levita, Integrale aanpak multiproblematiek en arbeidstoeleiding. Handreiking voor professionals die een integraal team opzetten of herijken, Radar Advies, in samenwerking met AStri Beleidsonderzoek- en Advies, Amsterdam/Leiden: april 2012.

Movisie, Op weg naar duurzame maatschappelijke ondersteuning. De inhoudelijke samenhang tussen de drie decentralisaties en de Wmo, Utrecht: november 2012.

Op het Veld, A. \& J. Wachtmeester, Decentralisatie betekent transitie \& transformatie. Nieuwe verantwoordelijkheden, rollen en opgaven in maatschappelijke ondersteuning, Andersson Elffers Felix bv (AEF), in opdracht van het TransitieBureau Begeleiding in de Wmo, Utrecht: januari 2012

Oude Vrielink, M., H. Koper \& L. Sterrenberg, Eén gezin, één plan, één regisseur: de gemeente aan zet, Bestuurskunde, 2013/3, p. 18-27.

Programmaministerie Jeugd en Gezin, Alle kansen voor alle kinderen, Beleidsprogramma Jeugd en Gezin 2007-2011, Den Haag: 2007.

Soeters M. \& G. Verhoeks, Integraal willen we allemaal?! Naar effectieve, efficiënte en klantvriendelijke maatschappelijke hulp, RVZ-rapport, Den Haag: maart 2010.

Steketee, M. \& M. Vandenbroucke, Typologie voor een strategische aanpak van multiprobleemgezinnen in Rotterdam. Een studie in het kader van Klein maar Fijn, Academische werkplaats CEPHIR, Rotterdam: juni 2010.

Tweede Kamer der Staten-Generaal, Regels over de gemeentelijke verantwoordelijkheid voor preventie, ondersteuning, hulp en zorg aan jeugdigen en ouders bij opgroei- en opvoedingsproblemen, psychische problemen en stoornissen (Jeugdwet), Memorie van Toelichting, Vergaderjaar 2012-2013, TK $33684 \mathrm{nr} .3$

Tweede Kamer der Staten-Generaal, Regels inzake de gemeentelijke ondersteuning op het gebied van zelfredzaamheid, participatie, beschermd wonen en opvang (Wet maatschappelijke ondersteuning 2015), Memorie van Toelichting, Vergaderjaar 2013-2014, TK 33841 nr. 3

Tweede Kamer der Staten-Generaal, Wijziging van de Wet werk en bijstand, de Wet sociale werkvoorziening, de Wet werk en arbeidsondersteuning jonggehandicapten en enige andere wetten gericht op bevordering deelname aan de arbeidsmarkt voor mensen met arbeidsver- 
mogen en harmonisatie van deze regelingen (Invoeringswet Wet werken naar vermogen), Vierde nota van wijziging, Vergaderjaar 2013-2014, TK 33 161, nr. 107

Uittenbogaard, B. (ed.), Werken met multiprobleemhuishoudens, Baarn: 2010.

VROM/WWI, Actieplan krachtwijken. Van aandachtswijk naar krachtwijk, Den Haag: juli 2007.

VROM/WWI, Voortgangsrapportage Wijkenaanpak, Den Haag: 2008.

Vereniging van Nederlandse Gemeenten, Interprovinciaal Overleg, Unie van Waterschappen en Rijk Bestuursakkoord 2011-2015, 21 april 2011. 